Research Paper

\title{
Investigation of the association between clinical outcome and the cag pathogenicity-island and other virulence genes of Helicobacter pylori isolates from patients with dyspepsia in Eastern Turkey
}

\author{
Gokben Ozbey ${ }^{1}$, Ulvi Demirel ${ }^{2}$, Cem Aygun $^{2}$, Hasan Basri Ertas ${ }^{3}$ \\ ${ }^{1}$ Vocational School of Health Services, Firat University, Elazig, Turkey. \\ ${ }^{2}$ Department of Gastroenterology, Faculty of Medicine, Firat University, Elazig, Turkey. \\ ${ }^{3}$ Department of Microbiology, Faculty of Veterinary Medicine, Firat University, Elazig, Turkey.
}

Submitted: March 20, 2012; Approved: April 4, 2013.

\begin{abstract}
The aims of our work were to determine the presence of the cag pathogenicity-island (cag PAI) and other virulence genes of Helicobacter pylori recovered from patients with gastritis and peptic ulcer, and to investigate the correlation of these virulence genes with clinical outcome. The presence of the $\operatorname{cag} A$, the promoter regions of $\operatorname{cag} A, \operatorname{cag} E, \operatorname{cag} T$, and the left end of $\operatorname{cag}$-PAI (LEC), cag right junction (cagRJ), the plasticity region open reading frames (ORFs), vacA and oipA genes among $69 \mathrm{H}$. pylori isolates were determined by polymerase chain reaction. Intact cag PAI was detected in only one (1.4\%) isolate. The $\operatorname{cag} A$ gene was identified in $52.1 \%$ and $76.2 \%$ of isolates from patients with dyspepsia (gastritis and peptic ulcer), respectively. The plasticity region ORFs i.e. JHP912 and JHP931 were predominantly detected in isolates from peptic ulcer. Less than $25 \%$ of the isolates carried other ORFs. Types I, II and III were the most commonly found among the isolates. None of the isolates possessed type Ib, 1c, IIIb, IV and V motifs. The most commonly vacA genotypes were s1am1a and s $1 \mathrm{~m} 2$ in isolates with peptic ulcer and gastritis, respectively. The results confirmed that the prevalence of oipA (Hp0638) gene was $75 \%$ and $85.7 \%$ in patients with gastritis and peptic ulcer, respectively. Furthermore, $v a c A$ s 1 am 1 a positivity was significantly related to peptic ulcer $(\mathrm{p}<0.05)$.
\end{abstract}

Key words: Helicobacter pylori, gastritis, peptic ulcer, cag pathogenicity-island, polymerase chain reaction.

\section{Introduction}

Helicobacter pylori (H. pylori) is a bacterial pathogen which can cause gastritis, peptic ulcer and gastric carcinoma (Cremonini et al., 2001; Saunders et al., 2005). Strains of H. pylori are classified into two types (types I and II) (Xiang et al., 1995: Hofman et al., 2000). Type I is a pathogenic form, correlates with severe disease status, expresses functional vacuolating cytotoxin A ( $v a c A)$ and includes an approximately $40 \mathrm{~kb}$ cluster located at 3' end of the cag pathogenicity island (cag PAI) (Censini et al., 1996; Ikenoue et al., 2001; Kersulyte et al., 2000; Mattar et al., 2007). Type II which is less virulent and includes a non-pathogenic form of vacA, lacks cag PAI (Censini et al., 1996; Backert et al., 2004).
The cag PAI is separated the two groups (cagI and cagII) by a novel insertion sequence called IS605 and these include at least 14 and 16 open reading frames (ORFs), respectively (Censini et al., 1996; Akopyants et al., 1998; Audibert et al., 2001; Mattar et al., 2007). The cytotoxin associated gene $\mathrm{E}(\mathrm{cag} E)$ gene which is needed for the induction of interleukin (IL)-8 from gastric epithelial cells is located in the cagI (Censini et al., 1996; Ikenoue et al., 2001; Tan et al., 2005). The cagT gene has been reported to be a marker of the cagII region (Mattar et al., 2007) and correlates with severe clinical outcomes (Mattar et al., 2007; Pacheco et al., 2008).

Comparison of the genome sequence analysis of $H$. pylori 26695 and J99 strains demonstrated several regions of different $\mathrm{G}+\mathrm{C}$ contents (Tomb et al., 1997; Alm et al., 
1999; Occhialini et al., 2000; Salih et al., 2007). From these regions, a large region in strains J99 and 26695 has been named as the "plasticity region" (Alm et al., 1999; Doig et al., 1999; Salih et al., 2007). In the J99 plasticity region (JHP914 to JHP951), the authors reported to observed to be 38 ORFs while 33 ORFs were not included in $H$. pylori 26695 , and the majority of the ORFs encode putative proteins with unknown function (Occhialini et al., 2000). However, some of ORFs have been determined to share similarity to genes encoding proteins included in DNA replication (JHP919 and JHP931) and other functions (JHP941 and JHP951) (Occhialini et al., 2000; Salih et al., 2007).

Till date, we studied on the presence of several genes, such as $\operatorname{cag} A, v a c A, \operatorname{cag} E$, induced by contact with epithelium (iceA) and blood adhesion binding antigen (babA2) among adults (Ozbey et al., 2012) and children (Ozbey et al., 2013) in Eastern Turkey. However, the data on identification of cag PAI and multiple virulence genes of $H$. pylori in Turkey is scarce. This study aimed to identify the presence of cag PAI and other virulence genes of $H$. pylori isolates from dyspeptic patients with gastritis and peptic ulcer in Elazig Province, the East of Turkey as well as to evaluate the relevance between the clinical outcome and the cag PAI and other virulence genes.

\section{Materials and Methods}

\section{Isolates}

A total of $69 \mathrm{H}$. pylori isolates (48 cases of gastritis and 21 cases of peptic ulcer) obtained from Turkish dyspeptic patients attending Gastroenterology Unit of Firat University Hospital between May and December 2011 were analyzed for the presence of cag PAI and other virulence genes. Ethics approval was given by the Medical Ethics Committee at Firat University and informed consent was ensured from each participant.

\section{DNA extraction and Determination of the cag-PAI and other virulence genes}

DNA samples from $H$. pylori isolates were extracted by QIAamp DNA mini kit (Qiagen, Germany) according to the manufacturer's guidelines.

PCR analyses were performed to amplify $\operatorname{cag} A$, the $\operatorname{cag} A$ promoter region, $\operatorname{cag} E, \operatorname{cag} T$, and the LEC of the $\operatorname{cag}$ PAI, as described elsewhere (Ikenoue et al., 2001; Kauser et al., 2004) (Table 1).

Primers which designed by Kersulyte et al. (2000), Mukhopadhyay et al. (2000), Veralovic et al. (1991) and Kauser et al. (2005a) were used to determine the presence of the cag right junction ( $\operatorname{cagRJ}$ ), the plasticity region ORFs, vacA and oipA (Hp0638) genes (Table 1).

Amplification reactions were performed using 2XPCR Master Mix kit (\#K01071, Fermentas) following the manufacturer's instructions in touchdown thermal cycler (Hybaid, England) with PCR conditions shown in Table 1 . Ten $\mu \mathrm{L}$ aliquot of each amplicon was expose to gel electrophoresis on a $1.5 \%$ agarose gel and visualised using a UV transilluminator.

\section{Statistical analysis}

Fischer's exact and $\chi^{2}$ tests were used to analyze significant differences between the cag PAI and other virulence genes of $H$. pylori isolates with the clinical outcome. A probability of less than 0.05 was evaluated significant.

\section{Results}

Table 2 shows the distribution of the cag PAI and other virulence genes of $H$. pylori isolates from cases of gastritis and peptic ulcer. The prevalence of LECI, LECII, $\operatorname{cag} E$, the promoter region of the $\operatorname{cag} A$ and $\operatorname{cag} A$ were detected more $(14.3 \%, 19 \%, 38.1 \%, 47.6 \%$ and $76.2 \%$, respectively) in isolates from peptic ulcer. One isolate (1.4\%; 1 of 69) were observed to possess the intact cag PAI.

Types I (6.3\%), II (4.2\%) and III (8.3\%) were observed predominantly in isolates from gastritis. However, Ia (19\%) and IIIa (23.8\%) motifs were the most common types in peptic ulcer isolates. None of the isolates contained type Ib, 1c, IIIb, IV and V motifs. The most predominant plasticity region ORFs were JHP912 and JHP931 and these two ORFs were identified more in isolates from peptic ulcer. Less than $25 \%$ of the isolates carried other ORFs (JHP926, JHP933, JHP944, JHP945, JHP986). The vacA slamla was the most extensively vacA genotype found in isolates with peptic ulcer while $\mathrm{s} 1 \mathrm{~m} 2$ was the most predominant genotype in patients with gastritis. However, no $v a c A \mathrm{~s} 1 \mathrm{c}, v a c A \mathrm{~m} 1 \mathrm{~b}$ and $v a c A \mathrm{~s} 2 \mathrm{~m} 1$ genotypes were demonstrated in the current study. The oipA gene was observed in $75 \%$ of isolates with gastritis and $85.7 \%$ of isolates with peptic ulcer.

Assesing the association between the cag PAI and other virulent genes with clinical outcome, $v a c A$ s1am1a genotype was shown to be statistically significant with peptic ulcer $(\mathrm{p}<0.05)$.

\section{Discussion}

Since its first identification by Censini et al. (1996) in 1996, the cag PAI part of the H. pylori genome has been widely studied so far (Olbermann et al., 2010; Rizzato et al., 2012).

Conflicting results have been obtained in studies on the prevalence of $\operatorname{cag} A$ gene in different geographical regions of the world. The prevalence of the $\operatorname{cag} A$ gene was $60-70 \%$ in Western countries (Rudi et al., 1998) but the prevalence in East Asian countries was detected to be found in more than 90\% of cases (Maeda et al., 1998; Yamaoka et al., 1999). This study was similar to that reported in Turkey (Salih et al., 2007) and Western countries (Covacc et al., 1999; Arents et al., 2001) where cagA gene were observed 


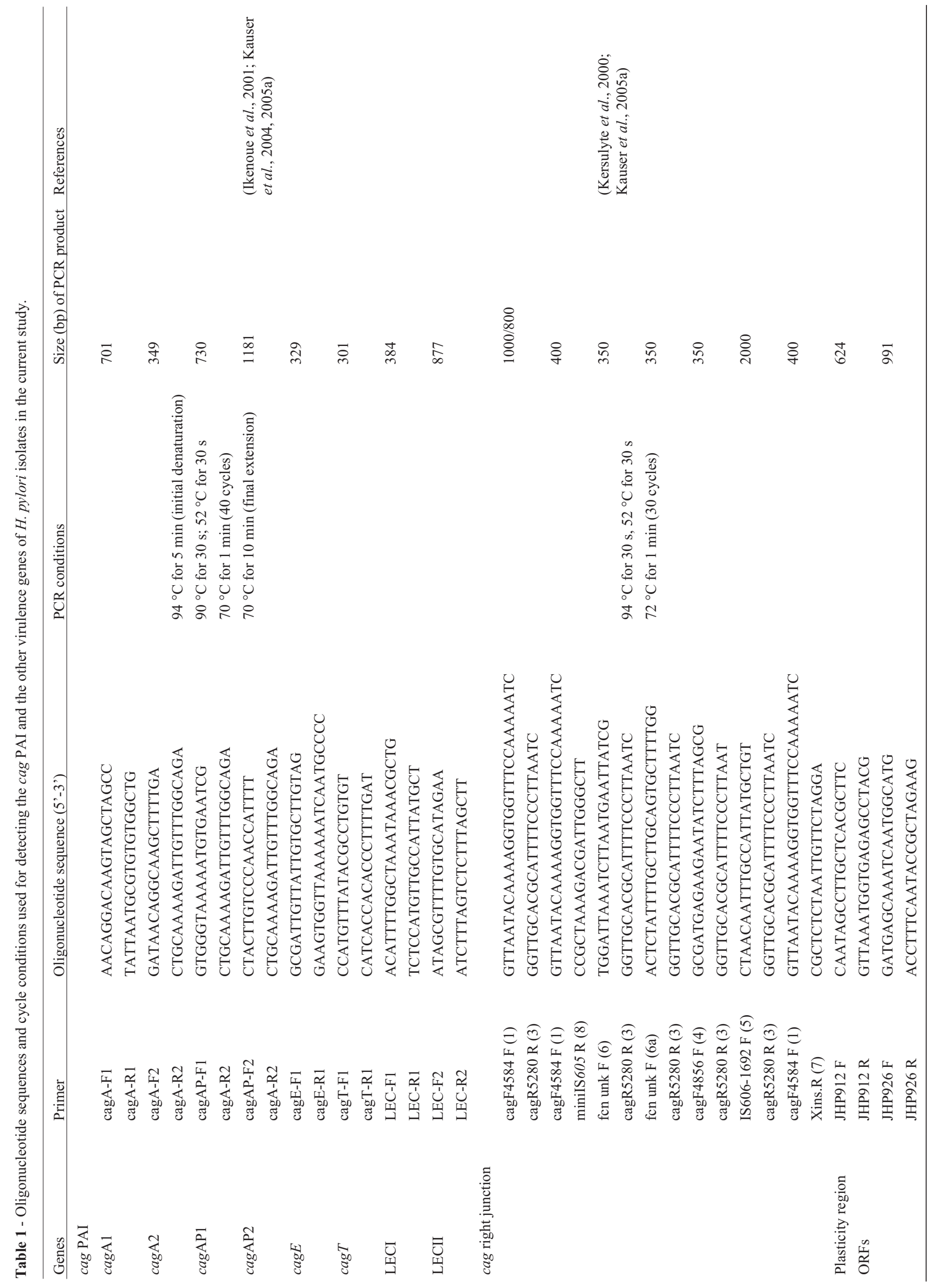




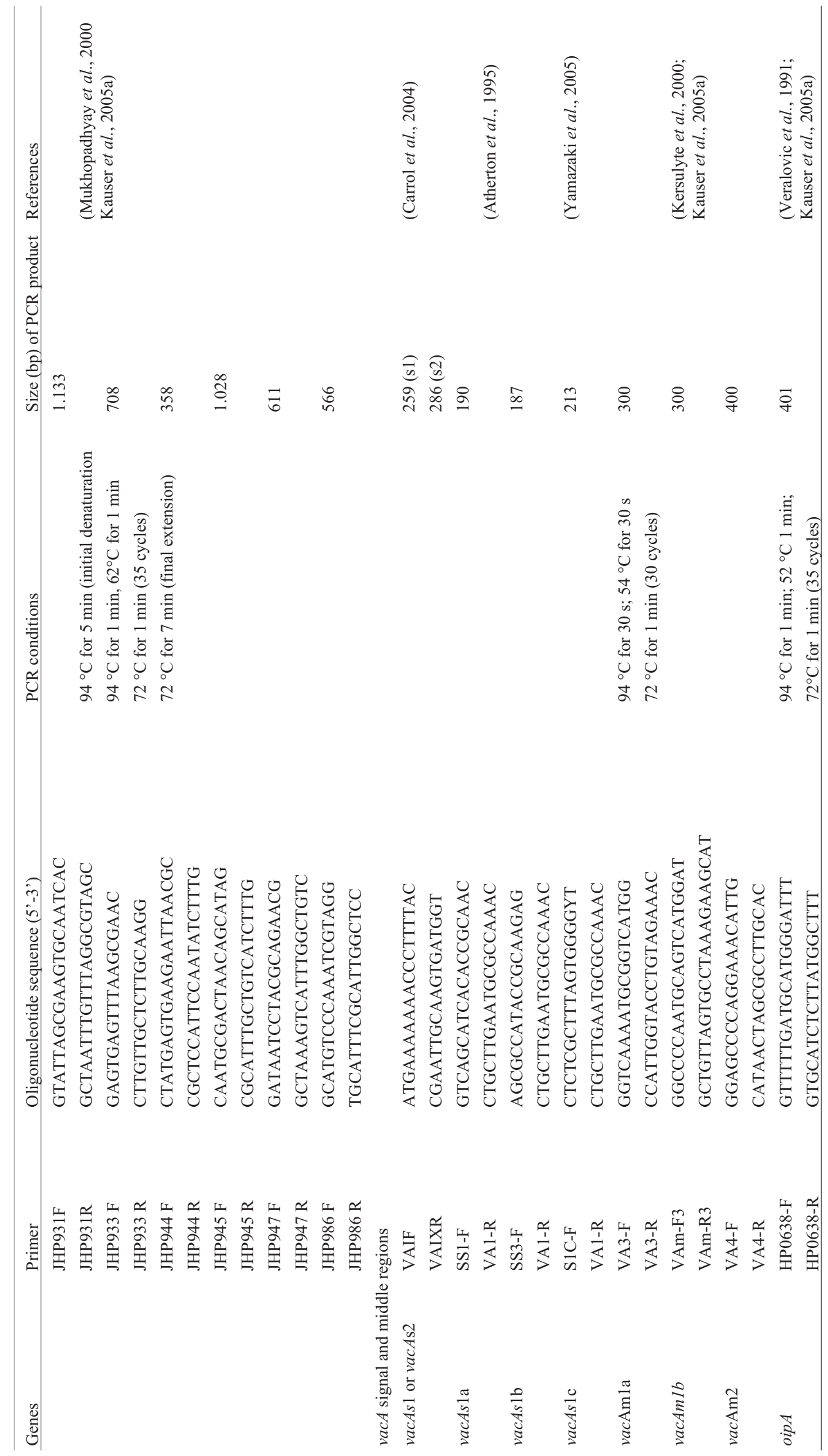


Table 2 - Distribution of the cag PAI and the other virulence genes of $H$. pylori isolates from cases of gastritis and peptic ulcer.

\begin{tabular}{|c|c|c|}
\hline cag PAI & Gastritis $(n=48)(\%)$ & Peptic ulcer $(n=21)(\%)$ \\
\hline LEC1 & $5(10.4)$ & $3(14.3)$ \\
\hline LEC2 & $3(6.3)$ & $4(19)$ \\
\hline $\operatorname{cag} T$ & $17(35.4)$ & $7(33.3)$ \\
\hline $\operatorname{cag} E$ & $16(33.3)$ & $8(38.1)$ \\
\hline cagAP & $8(16.7)$ & $10(47.6)$ \\
\hline $\operatorname{cag} A$ & $25(52.1)$ & $16(76.2)$ \\
\hline \multicolumn{3}{|l|}{ cagRJ region } \\
\hline Type I & $3(6.3)$ & $1(4.8)$ \\
\hline Type Ia & 0 & $4(19)$ \\
\hline Type II & $2(4.2)$ & 0 \\
\hline Type III & $4(8.3)$ & 0 \\
\hline Type IIIa & $1(2.1)$ & $5(23.8)$ \\
\hline \multicolumn{3}{|l|}{ ORFs } \\
\hline JHP912 & $25(52.1)$ & $14(66.7)$ \\
\hline JHP926 & $1(2.1)$ & $0(0)$ \\
\hline JHP931 & $15(31.3)$ & $9(42.9)$ \\
\hline JHP933 & $10(20.8)$ & $5(23.8)$ \\
\hline JHP944 & $8(16.7)$ & $3(14.3)$ \\
\hline JHP945 & $11(22.9)$ & $4(19)$ \\
\hline JHP986 & $6(12.5)$ & $1(4.8)$ \\
\hline \multicolumn{3}{|l|}{$v a c A$ alleles } \\
\hline vacAsla & $35(72.9)$ & $19(90.5)^{*}$ \\
\hline$v a c \mathrm{As} 1 \mathrm{~b}$ & $2(4.2)$ & $0(0)$ \\
\hline vacAs2 & $11(22.9)$ & $2(9.5)$ \\
\hline$v a c \mathrm{Am} 1 \mathrm{a}$ & $10(20.8)$ & $15(71.4)^{*}$ \\
\hline vacAm2 & $38(79.2)$ & $6(28.6)$ \\
\hline oipA & $36(75)$ & $18(85.7)$ \\
\hline
\end{tabular}

*significant $\mathrm{p}<0.05$.

to be higher in peptic ulcer patients compared to gastritis. We confirmed that no relevance between the $\operatorname{cag} A$ and gastroduodenal disease in the present study which was in accordance with previous studies (Hussein et al., 2008; Baghaei et al., 2009). However, other studies (Gunn et al., 1998; Basso et al., 2008) represented an association.

Previous studies reported that strains which lack the $\operatorname{cag} T$ gene had a defective 'molecular syringe' (Rohde et al., 2003; Kauser et al., 2005b). We represented that isolates from gastritis and peptic ulcer carried cagE and cagT with almost similar proportion. In a study performed in England, most of strains obtained from ulcer patients retained the $\operatorname{cag} E$ and $\operatorname{cag} T$ (Kauser et al., 2005b). A pevious study has shown that the $c a g E$ is a better marker of an intact cag PAI in Japanese strains (Ikenoue et al., 2001) which is in contrast with our findings. Kauser et al. (2004) and Matteo et al. (2007) described that a conserved LEC region was rearranged more in strains related to severe pathology worldwide.

The prevalence of the cag PAI varies in different geographical regions. There was only one report concerning the distribution of the cag PAI and the ORFs of H. pylori strains in Turkey (Salih et al., 2007). Previous reports showed that an intact cag PAI gene was highly observed in Japanese, Malaysia and Singapore strains, least found in European and African strains, and very poorly found in Peruvian, Indian, Iranian and Turkish strains (Kauser et al., 20004; Baghaei et al., 2009; Salih et al., 2007; Schmidt et al., 2010). Our results also support the findings (Baghaei et al., 2009; Rudi et al., 1998) indicated that an intact cag PAI gene was detected to be low prevalence in Iranian and Turkish strains. This could be due to geographical closeness, the similar condition of life and diet in Iran and Turkey (Baghaei et al., 2009). An intact cag PAI may be underestimated when a selective primers were used since cag PAI was encoded by $\sim 40 \mathrm{~kb}$ gene (Schmidt et al., 2010).

Five main types (I, II, III, IV and V) were detected at the $c a g$ RJ region and scientists reported that the three types (I, II and III) were prevalent (Kersulyte et al., 2000). The authors indicated that type IIIa or type I were observed in $28.8 \%$ of the motifs in England strains and some of the European strains share similar profiles with the Asian strains (Kauser et al., 2005b) The results of the current study are also supportive of a previous study that Turkish strains showed to be predominant of types I, II and III which were no associated with the severity of the disease (Salih et al., 2007).

Among the plasticity region ORFs, JHP940 and JHP947 have been observed more in strains with gastric cancer (Occhialini et al., 2000). Our data is similar to the previous reports in Costa Rica, Netherlands and Turkey where the prevalence of JHP0945 was almost similar proportions between $\mathrm{H}$. pylori isolates obtained from gastritis and peptic ulcer (Occhialini et al., 2000; de Jonge et al., 2004; Salih et al., 2007) but different from a study (Sugimoto et al., 2012) which demonstrated that the prevalence of JHP0945 was found to be higher in isolates with peptic ulcer. We observed that JHP0931 gene was not associated with clinical disease in the present work which was in consistent with a study in Costa Rica (Occhialini et al., 2000). However, Salih et al. (2007) found that JHP912 and JHP931 genes was significant association in cases with peptic ulcer in Turkey.

The H. pylori oipA which have great antigenic characteristics and increase the serum level of IL- 8 besides the clinically important demonstration of peptic ulcer, is an important virulence factor (Yamaoka et al., 2002; Zambon et al., 2002; Kudo et al., 2004). We showed no significant correlation between the oipA gene and peptic ulcer, in contrast with a previous study (Salih et al., 2007) performed in Turkey. 
In a study carried out in Turkey, the authors detected that the most predominantly genotype among type II isolates was $\mathrm{s} 1 / \mathrm{m} 2$, but except for one patient with gastritis and gastric ulcer possessed $\mathrm{s} 1 / \mathrm{m} 2$ genotype, all type I isolates had s1/m1 genotype (Nagiyev et al., 2009). This study showed that none of H. pylori isolates had vacAm1b genotype. Our study is concurrence with previous studies (Blaser et al., 1995; Salih et al., 2007) which reported that $\mathrm{s} 1 \mathrm{a} / \mathrm{m} 1 \mathrm{a}$ was the most prevalent genotype among isolates with peptic ulcer. In contrast, $\mathrm{s} 1 \mathrm{c} / \mathrm{m} 1 \mathrm{~b}$ and $\mathrm{s} 1 \mathrm{a} / \mathrm{m} 1 \mathrm{~b}$ strains were the predominant genotypes in East Asian countries (Yamazaki et al., 2005). We found that the $\mathrm{s} 1 \mathrm{~m} 2$ strains were predominantly detected in isolates from gastritis. Our findings were similar to the previous reports in Turkey (Erzin et al., 2006; Nagiyev et al., 2009) where the vacAs1a strains showed to be significantly correlated with peptic ulcer.

In conclusion, this study suggests that $\operatorname{cag} A$, oip $A$, JHP912, JHP931 and vacA s1am1a were the most common genes in isolates with peptic ulcer, and vacAslamla was significantly correlated with peptic ulcer. When considering the worldwide distribution of $\mathrm{H}$. pylori as a common pathogen, further larger scale researches are necessary to be conducted in strains obtained from different geographical regions in order to assess the possible role of cag PAI and other virulence genes in different clinical outcomes which is correlated with $\mathrm{H}$. pylori infections.

\section{Acknowledgments}

The authors appreciated Dr. Alfizah Hanafiah (Department of Medical Microbiology and Immunology, Faculty of Medicine, UKM Medical Centre, Kuala Lumpur, Malaysia), Dr. Guillermo I. Perez Perez (NYU School of Medicine, Department of Medicine and Microbiology, New York, USA) and Dr. Ikuko Kato (Karmanos Cancer Institute, Wayne State University, Detroit, Michigan, USA) for their assistance with the correction of the manuscript. In addition, we thank to the management of the Elazig Veterinary Control and Research Institute for ensuring laboratory facilities during our study.

\section{References}

Akopyants NS, Clifton SW, Kersulyte D, Crabtree JE, Youree BE, Reece CA, Bukanov NO, Drazek ES, Roe BA, Berg DE (1998) Analyses of the cag pathogenicity island of Helicobacter pylori. Mol Microbiol 28:37-53.

Alm RA, Ling LSL, Moir DT, King BL, Brown ED, Doig PC, Smith DR, Noonan B, Guild BC, De Jonge BL, Carmel G, Tummino PJ, Caruso A, Uria-Nickelsen M, Mills DM, Ives C, Gibson R, Merberg D, Mills SD, Jiang Q, Taylor DE, Vovis GF, Trust TJ (1999) Genomic-sequence comparison of two unrelated isolates of the human gastric pathogen Helicobacter pylori. Nature 397:176-180.

Arents NL, Van ZAA, Thijs JC, Kornelis-Smid AMD, van Slochteren KR, Degener JE, Kleibeuker JH, van Doorn LJ (2001) The importance of vacA cagA and iceA genotypes of
Helicobacter pylori infection in peptic ulcer disease and Gastroesopharyngeal reflux disease. Am J Gastroenterol 96:2603-2608.

Atherton JC, Cao P, Peek RM Jr, Tummuru MK, Blaser MJ, Cover TL (1995) Mosaicism in vacuolating cytotoxin alleles of Helicobacter pylori. Association of specific vacA types with cytotoxin production and peptic ulceration. J Biol Chem 270:17771-17777.

Audibert C, Burucoa C, Janvier B, Fauchère JL (2001) Implication of the structure of the Helicobacter pylori cag pathogenicity island in induction of interleukin-8 Secretion. Infect Immun 69:1625-1629.

Backert S, Schwarz T, Miehlke S, Kirsch C, Sommer C, Kwok T, Gerhard M, Goebel UB, Lehn N, Koenig W, Meyer TF (2004) Functional analysis of the cag pathogenicity island in Helicobacter pylori isolates from patients with gastritis, peptic ulcer and gastric cancer. Infect Immun 72:1043-1056.

Baghaei K, Shokrzadeh L, Jafari F, Dabiri H, Yamaoka Y, Bolfion M, Zojaji H, Aslani M, Zali MR (2009) Determination of Helicobacter pylori virulence by analysis of the cag pathogenicity island isolated from Iranian population. Dig Liver Dis 41:634-638.

Basso D, Zambon CF, Letley DP, Stranges A, Marchet A, Rhead JL, Schiavon S, Guariso G, Ceroti M, Nitti D, Rugge M, Plebani M, Atherton JC (2008) Clinical relevance of Helicobacter pylori cagA and vacA gene polymorphisms. Gastroenterology 135:91-99.

Blaser MJ, Perez-Perez GI, Kleanthous H, Cover TL, Peek RM, Chyou PH, Stemmermann GN, Nomura A (1995) Infection with Helicobacter pylori strains possessing cagA is associated with an increased risk of developing adenocarcinoma of the stomach. Cancer Res 55:2111-2115.

Carroll IM, Ahmed N, Beesley SM, Khan AA, Ghousunnissa S, Morain CA, Habibullah CM, Smyth CJ (2004) Microevolution between paired antral and paired antrum and corpus Helicobacter pylori isolates recovered from individual patients. J Med Microbiol 53:1-9.

Censini S, Lange C, Xiang Z, Crabtree JE, Ghiara P, Borodovsky M, Rappuoli R, Covacci A (1996) cag, a pathogenicity island of Helicobacter pylori, encodes type I-specific and disease-associated virulence factors. Proc Natl Acad Sci USA 93:14648-14653.

Covacci A, Telford JL, Giudice GD, Parsonnet J, Rappuoli R (1999) Helicobacter pylori virulence and genetic geography. Science 284:1328-1333.

Cremonini F, Gasbarrini A, Armuzzi A, Gasbarrini G (2001) Helicobacter pylori-related diseases. Eur J Clin Invest 31:431-437.

de Jonge R, Kuipers EJ, Langeveld SCL, Loffeld RJLF, Stoof J, van Vliet AHM, Kusters JG (2004) The Helicobacter pylori plasticity region locus jhp0947-jhp0949 is associated with duodenal ulcer disease and interleukin-12 production in monocyte cells. FEMS Immunol Med Microbiol 41:161-167.

Doig P, De Jonge BL, Alm RA, Brown ED, Uria-Nickelsen M, Noonan B, Mills SD, Tummino P, Carmel G, Guild BC, Moir DT, Vovis GF, Trust TJ (1999) Helicobacter pylori physiology predicted from genomic comparison of two strains. Microbiol Mol Biol Rev 63:675-707.

Erzin Y, Koksal V, Altun S, Dobrucali A, Aslan M, Erdamar S, Dirican A, Kocazeybek B (2006) Prevalence of Helicobacter pylori vacA, cagA, cagE, iceA, babA2 geno- 
types and correlation with clinical outcome in Turkish patients with dyspepsia. Helicobacter 11:574-580.

Gunn MC, Stephens JC, Stewart JA, Rathbone BJ, West KP (1998) The significance of cagA and vacA subtypes of Helicobacter pylori in the pathogenesis of inflammation and peptic ulceration. J Clin Pathol 51:761-764.

Hofman V, Ricci V, Galmiche A, Brest P, Auberger P, Rossi B, Boquet P, Hofman P (2000) Effect of Helicobacter pylori on polymorphonuclear leukocyte migration across polarized T84 epithelial cell monolayers: role of vacuolating toxin VacA and cag pathogenicity island. Infect Immun 68:52255233.

Hussein NR, Mohammadi M, Talebkhan Y, Doraghi M, Letley DP, Muhammad MK, Argent RH, Atherton JC (2008) Differences in virulence markers between Helicobacter pylori strains from Iraq and those from Iran: potential importance of regional differences in $H$. pylori-associated disease. J Clin Microbiol 46:1774-1779.

Ikenoue T, Maeda S, Gura KO, Akanuma M, Mitsuno Y, Imai Y, Yoshida H, Shiratori Y, Omata M (2001) Determination of Helicobacter pylori virulence by simple gene analysis of the cag pathogenicity island. Clin Diagn Lab Immunol 8:181186.

Kauser F, Khan AA, Hussain MA, Carroll IM, Ahmad N, Tiwari S, Shouche Y, Das B, Alam M, Ali SM, Habibullah CM, Sierra R, Megraud F, Sechi LA, Ahmed N (2004) The cag pathogenicity island of Helicobacter pylori is disrupted in the majority of patient isolates from different human populations. J Clin Microbiol 42:5302-5308.

Kauser F, Hussain MA, Ahmed I, Ahmad N, Habeeb A, Khan AA, Ahmed N (2005a) Comparing genomes of Helicobacter pylori strains from the high altitude desert of Ladakh, India. J Clin Microbiol 43:1538-1545.

Kauser F, Hussain MA, Ahmed I, Srinivas S, Devi SM, Majeed AA, Rao KR, Khan AA, Sechi LA, Ahmed N (2005b) Comparative genomics of Helicobacter pylori isolates recovered from ulcer disease patients in England. BMC Microbiol $5: 32-42$.

Kersulyte D, Mukhopadhyay AK, Velapatino B, Su WW, Pan ZJ, Garcia C, Hernandez V, Valdez Y, Mistry RS, Gilman RH, Yuan Y, Gao H, Alarcon T, Lopez-Brea M, Nair GB, Chowdhury A, Datta S, Shirai M, Nakazawa T, Ally R, Segal I, Wong BCY, Lam SK, Olfat F, Boren T, Engstrand L, Torres O, Schneider R, Thomas JE, Czinn S, Berg DE (2000) Differences in genotypes of Helicobacter pylori from different human populations. J Bacteriol 182:3210-3218.

Kudo T, Nurgalieva ZZ, Conner ME, Crawford S, Odenbreit S, Haas R, Graham DY, Yamaoka Y (2000) Correlation between Helicobacter pylori OipA protein expression and oipA gene switch status. J Clin Microbiol 42:2279-2281.

Maeda S, Ogura K, Yoshida H, Kanai F, Ikenoue T, Kato N, Shiratori Y, Omata M (1998) Major virulence factors, VacA and CagA, are commonly positive in Helicobacter pylori isolates in Japan. Gut 42:338-343.

Mattar R, Marques SB, Monteiro MS, dos Santos AF, Iriya K, Carrilho FJ (2007) Helicobacter pylori cag pathogenicity island genes: clinical relevance for peptic ulcer disease development in Brazil. J Med Microbiol 56:9-14.

Matteo MJ, Granados G, Pérez CV, Olmos M, Sanchez C, Catalano M (2007) Helicobacter pylori cag pathogenicity island genotype diversity within the gastric niche of a single host. J Med Microbiol 56:664-669.

Mukhopadhyay AK, Kersulyte D, Jeong JY, Datta S, Ito Y, Chowdhury A, Chowdhury S, Santra A, Bhattacharya SK, Azuma T, Nair GB, Berg DE (2000) Distinctiveness of genotypes of Helicobacter pylori in Calcutta, India. J Bacteriol 182:3219-3227.

Nagiyev T, Yula E, Abayli B, Koksal F (2009) Prevalence and genotypes of Helicobacter pylori in gastric biopsy specimens from patients with gastroduodenal pathologies in the Cukurova region of Turkey. J Clin Microbiol 47:4150-4153.

Occhialini A, Marais A, Alm R, Garcia F, Sierra R, Megraud F (2000) Distribution of open reading frames of plasticity region of strain $\mathrm{J} 99$ in Helicobacter pylori strains isolated from gastric carcinoma and gastritis patients in Costa Rica. Infect Immun 68:6240-6249.

Olbermann P, Josenhans C, Moodley Y, Uhr M, Stamer C, Vauterin M, Suerbaum S, Achtman M, Linz B (2010) A global overview of the genetic and functional diversity in the Helicobacter pylori cag pathogenicity island. PLoS Genet 6:e1001069.

Ozbey G, Aygun C (2012) Prevalence of genotypes in Helicobacter pylori isolates from patients in eastern Turkey and the association of these genotypes with clinical outcome. Braz J Microbiol 43:1332-1339.

Ozbey G, Dogan Y, Demiroren K (2013) Prevalence of Helicobacter pylori virulence genotypes among children in Eastern Turkey. World J Gastroenterol 19:6585-6589.

Pacheco AR, Proenca-Modena JL, Sales AI, Fukuhara Y, da Silveira WD, Pimenta-Modena JL, de Oliveira RB, Brocchi, M (2008) Involvement of the Helicobacter pylori plasticity region and cag pathogenicity island genes in the development of gastroduodenal diseases. Eur J Clin Microbiol Infect Dis 27:1053-1059.

Rizzato C, Torres J, Plummer M, Muñoz N, Franceschi S, Camorlinga-Ponce M, Fuentes-Pananá EM, Canzian F, Ikuko Kato I (2012) Variations in Helicobacter pylori cytotoxinassociated genes and their influence in progression to gastric cancer: Implications for Prevention. PLoS One 7:e29605.

Rohde M, Puls J, Buhrdorf R, Fischer W, Haas R (2003) A novel sheathed surface organelle of the Helicobacter pylori Cag type IV secretion system. Mol Microbiol 49:219-234.

Rudi J, Kolb C, Maiwald M, Kuck D, Sieg A, Galle PR, Stremmel W (1998) Diversity of Helicobacter pylori vacA and cagA genes and relationship to $v a c A$ and $\operatorname{cag} A$ protein expression, cytotoxin production, and associated diseases. J Clin Microbiol 36:944-948.

Salih BA, Abasiyanik MF, Ahmed N (2007) A preliminary study on the genetic profile of cag pathogenicity-island and other virulent gene loci of Helicobacter pylori strains from Turkey. Infect Genet Evol 7:509-512.

Saunders NJ, Boonmee P, Peden JF, Jarvis SA (2005) Interspecies horizontal transfer resulting in core-genome and niche-adaptive variation within Helicobacter pylori. BMC Genomics 6:9.

Schmidt H-M Andres S, Nilsson C, Kovach Z, Kaakoush NO, Engstrand L, Goh K-L, Fock KM, Forman D, Mitchell HM (2010) The cagPAI is intact \& functional but HP0521 varies significantly in Helicobacter pylori isolates from Malaysia \& Singapore. Eur J Clin Microbiol Infect Dis 29:439-451. 
Sugimoto M, Watada M, Jung SW, Graham DY, Yamaoka Y (2012) Role of Helicobacter pylori plasticity region genes in development of gastroduodenal disease. J Clin Microbiol 50:441-448.

Tan HJ, Rizal AM, Rosmadi MY, Goh KL (2005) Distribution of Helicobacter pylori cagA, cagE and vacA in different ethnic groups in Kuala Lumpur, Malaysia. J Gastroenterol Hepatol 20:589-594.

Tomb JF, White O, Kerlavage AR, Clayton RA, Sutton GG, Fleischmann RD, Ketchum KA, Klenk HP, Gill S, Dougherty BA, Nelson K, Quackenbush J, Zhou L, Kirkness EF, Peterson S, Loftus B, Richardson D, Dodson R, Khalak HG, Glodek A, McKenney K, Fitzegerald LM, Lee N, Adams MD, Hickey EK, Berg DE, Gocayne JD, Utterback TR, Peterson JD, Kelley JM, Cotton MD, Weidman JM, Fujii C, Bowman C, Watthey L, Wallin E, Hayes WS, Borodovsky M, Karp PD, Smith HO, Fraser CM, Venter JC (1997) The complete genome sequence of the gastric pathogen Helicobacter pylori. Nature 388 539-547.

Veralovic J, Koeuth T, Lupski JR (1991) Distribution of repetitive DNA sequences in Eubacteria and application to fingerprinting of bacterial genomes. Nucleic Acids Res 19:6823-6831.

Xiang ZY, Censini S, Bayeli PF, Telford JL, Figura N, Rappuoli R, Covacci A (1995) Analysis of expression of CagA and VacA virulence factors in 43 strains of Helicobacter pylori reveals that clinical isolates can be divided into two major types and that CagA is not necessary for expression of the vacuolating cytotoxin. Infect Immun 63:94-98.

Yamaoka Y, Kodama T, Gutierrez O, Kim JG, Kashima K, Graham DY (1999) Relationship between Helicobacter pylori ice $A, \operatorname{cag} A$, and $v a c A$ status and clinical outcome: studies in four different countries. J Clin Microbiol 37:2274-2279.

Yamaoka Y, Kikuchi S, El-Zimaity HM, Gutierrez O, Osato MS, Graham DY (2002) Importance of Helicobacter pylori oipA in clinical presentation, gastric inflammation, and mucosal interleukin-8 production. Gastroenterology 123:414-424.

Yamazaki S, Yamakawa A, Okuda T, Ohtani M, Suto H, Ito Y, Yamazaki Y, Keida Y, Higashi H, Hatakeyama M, Azuma T (2005) Distinct diversity of $v a c A, \operatorname{cag} A$, and $\operatorname{cag} E$ genes of Helicobacter pylori associated with peptic ulcer in Japan. J Clin Microbiol 43:3906-3916.

Zambon CF, Basso D, Navaglia F, Germano G, Gallo N, Milazzo M, Greco E, Fogar P, Mazza S, Di Mario F, Basso G, Rugge M, Plebani M (2002) Helicobacter pylori virulence genes and host $I L-1 R N$ and $I L-1 \beta$ genes interplay in favouring the development of peptic ulcer and intestinal metaplasia. Cytokine 18:242-251.

All the content of the journal, except where otherwise noted, is licensed under a Creative Commons License CC BY-NC. 